\title{
Characteristics of Air Filter Media Used for Monitoring Airborne Radioactivity
}

L. B. Lockhart, Jr. and R. L. Patterson, Jr.

\author{
Physical Chemistry Branch \\ Chemistry Division \\ and \\ W. L. Anderson \\ Protective Chemistry Branch \\ Chemistry Division
}

March 20, 1964

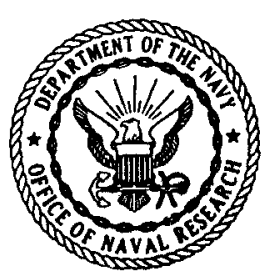

PATENT CLEARANCY

THE PUBLIC IS APPRUV...

ARE ON EILE IN THE RECEIVING -

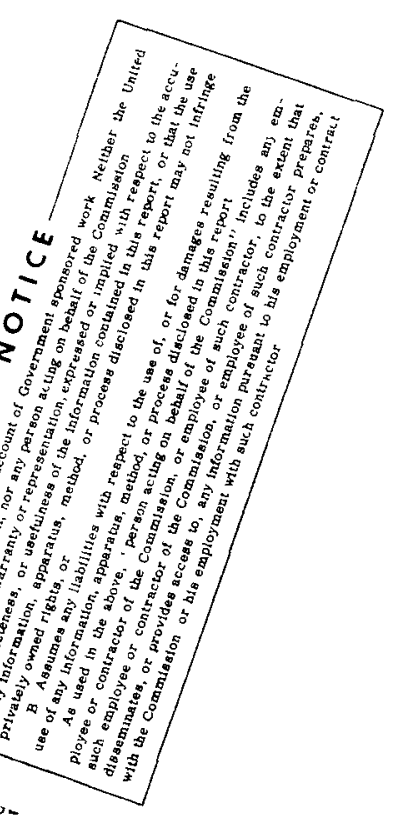

U.S. NAVAL RESEARCH LABORATORY

Washington, D.C. 


\section{DISCLAIMER}

This report was prepared as an account of work sponsored by an agency of the United States Government. Neither the United States Government nor any agency Thereof, nor any of their employees, makes any warranty, express or implied, or assumes any legal liability or responsibility for the accuracy, completeness, or usefulness of any information, apparatus, product, or process disclosed, or represents that its use would not infringe privately owned rights. Reference herein to any specific commercial product, process, or service by trade name, trademark, manufacturer, or otherwise does not necessarily constitute or imply its endorsement, recommendation, or favoring by the United States Government or any agency thereof. The views and opinions of authors expressed herein do not necessarily state or reflect those of the United States Government or any agency thereof. 


\section{DISCLAIMER}

Portions of this document may be illegible in electronic image products. Images are produced from the best available original document. 


\section{CONTENTS}

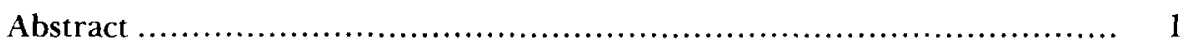

Problem Status ............................................................ 1

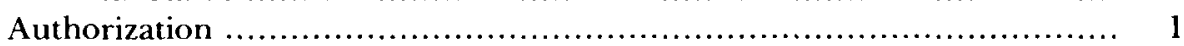

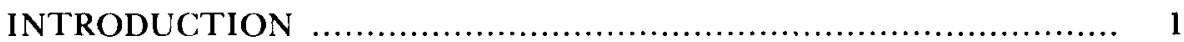

EXPERIMENTAL PROCEDURE AND RESULTS …..................... 2

Laboratory Evaluation ................................................... 3

Field Evaluation of Filter Retentivity ................................ 5

Field Evaluation of Other Filter Characteristics $\ldots \ldots \ldots \ldots \ldots \ldots \ldots \ldots \ldots . \ldots \ldots$

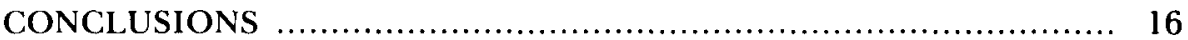

ACKNOWLEDGMENT .................................................. 17

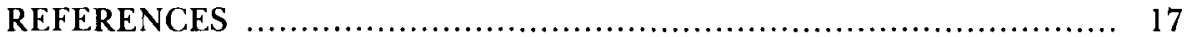




\title{
Characteristics of Air Filter Media Used For Monitoring Airborne Radioactivity
}

\author{
L. B. Lockhart, Jr. and R. L. Patterson, Jr. \\ Physical Chemistry Branch \\ Chemestry Division \\ and \\ W. L. ANDERSON \\ Protective Chemistry Branch \\ Chemustry Division
}

\begin{abstract}
A companison has been made of the more important characteristics of the avaldable filter materials which ase currently in use by idious systems for montoring arborne idiodctivity throughout the world. Most of the materials described are commercially dvallable; the infor mation herein is presented with the hope that it will be of use to those whose programs involve the employment of arr-filtci media on who scquire such information for the design of dir-filter sy stems

The filtes (haracteristics measured die such physic al propet ties as tenstle strength, thickness, density, ash content, tetentivity toward $03 \mu$ dioctyl phthalate (DOP) aerosol particles as a funcuon of air velocity, ietentwits towat darborne fission products and natut al radioactive aerosols (i ddon daughters) at several air velocities, flow rate as a function of pressure drop across the filter, and the relative idtes of clogging by at mospheric dust

I he observation of a rapid change in flow with dust loading of some of the filter media suggests the systematic study of un h changes as possibly a simple procedure for monitoning the dust content of the atmosphere.
\end{abstract}

\section{INTRODUCTION}

Air filtration is widely employed in studying the aerosol content of the atmosphere, since by this means it is possible to secure relatively large samples of airborne materials whose actual concentrations are generally extremely small. Such collections are followed by physical and chemical studies, often including weighing, to determine the concentration of contaminants in the air sample; in the case of airborne radioactivits, special techniques for evaluating the $\alpha, \beta$, or $\gamma$ activities of the collections are employed.

In the course of their independent development by various agencses and for valying purposes, a number of filtration sistems and filtration media have been employed in monitoring the radioactivity of the atmosphere. For some purposes it has been sufficient to collect enough material to be able to detect a significant (order

NR1 Problems A02-13 and (05-17, P1ojects RR 004-02-42-5151 and RR 001-0) 43-470), IH (Projed A I (49-7-2495) I has is a tinal teport on this phase of the problemis, athat work on the se problems is conturuing Manuscupt submuted Dec ember 18,1963 of magnitude) change in the concentration of airborne radioactive products; for others it has been necessary to collect, insofar as is possible, all radioactivity in a given quantity of air. The first case would thus have less stringent requirements on filter retentivity than the latter.

The filter retentivity, filter size, and the type and capacity of the blower are interrelated in that filters having the higher retentivities generally have greater resistance and hence require more powerful blowers to move a given volume of air in the same time interval; furthermore, the retentivity of most filter media for a given size particle increases as the linear velocity of the air through the filter increases. These factors, together with the different purposes for which air sampling systems have been devised, lead to a number of different possible combinations of filters and blowers.

Practical monitoring systems for determining 1 adioactivity in the air vary widely, depending on the ultimate pur pose for which the sample is being collected. For general monitoring, whose purpose is to serve as an alert or an alarm to initiate 
protective measures, a relatively inefficient filter can be tolerated so as to obtain the maximum collection of activity in a given time interval Small losses of activity through the filter or absolute calibrations of sampled volume are of secondary importance On the other hand, for the scientific study of airborne radioactivity, particularly when sotope ratios are of interest, it is essential to employ filters which retain essentially all of the particles containing radioactivity, the use of positive displacement or turbine-type blowers and of accurate means for determining airflow is also indicated

It should be noted, however, that systems can be overdesigned for a given task, utilizing costly, highly efficient filters and powerful blower systems when they are not necessarily required While the main purpose of this study has been to determine the effectiveness of various filter media under different operatıng conditions, this study also indicates areas where certan media may have an economic or operatıonal advantage at no loss in effectuveness

Filter retentivity depends on a number of factors such as pore size, fiber size, mat thickness, filter compaction or density, development of an electrostatic charge, stze and density of the entrained particle, and the velocity of air movement through the filter The most effective filters depend primarily on the retention of particles through the sieve action of small pores developed through compaction or other processes, or through the interception of the particles by a mat of fine fibers as the result of either a diffusion or impaction mechanism In most cases combinations of the above factors plus electrostatic effects are operating The physical parameters of the filter media determine the mechanism of collection and the ddaptability of the filter to subsequent analytical schemes

The more common filters die of the fibrous type employing fibers of cellulose (cotton, esparto), synthetı organıc materials (polystyrene, Idyon), glass, asbestos, or combinations thereof, organic binders or gums are often added to increase stiength (but with an increase in resistance) Membrane-type filters made of synthetic organic materials represent filters whose operation is largely sieve-like, though electrostatic and impdction processes impart a retentivity toward some airborne particles which are small enough dimensionally to pass through the pores in these filters
The cellulose and synthetic organic filters afford an advantage in processing, since they are easily decomposed by burning and dre essentrally ashless, on the other hand, there is often an advantage associated with the presence of ash as obtained from glass or asbestos fibers, because a finite amount of material is avallable to observe and manıpulate Sutable chemical processes are avalable to dissolve enturely the ash from either glass or asbestos filters or, indeed, to dissolve any of these filter media without ashing The latter is usually the preferred procedure, since there is less danger of loss of volatile elements

In addition to such fundamental factors as the retentivity and flow characteristics of the filters, the rate of change of flow with dust loading is of great importance, particularly when the collection period is measured in terms of hours or days rather than minutes The highly compacted filters, which are essentially surface collectors, are particularly susceptible to loss in flow through dust loading while the fibrous mats, with loose or less rigidly defined surfaces, show the least changes in resistance with time On the other hand, for some purposes, namely when the filters die to be used for subsequent $\alpha$ counting, only a front-surface collector can be used because of the importance of absorption of $\alpha$ energy by the filter medium for the more deeply penetrated surfaces

\section{EXPERIMENTAL PROCEDURE AND RESULTS}

An attempt has been made to secure for study as many as possible of the varıous filter media in use throughout the world for monitoring the atmosphere for radioactive particulate matter These media have been secured by the exchange of filter samples with agencies and institutions which employ filters not i eadily acquired by direct purchase in the United States As a result of the interest and cooperation of many individuals and groups, a wide spectrum of filter medra has been accumulated and studied Unfortunately, however, the material from several major an sampling networks is not covered in this study, thus far, attempts to interest scientists in the USSR in an exchange of filter samples have been unsuccessful Information published in summary reports issued by the US Atomic Energy Commission (1) and the European Nuclear Energy 
Agency (2) has been useful in determming the extent to which the different filter media have been employed A summary of the aur-filter medid in use by the various organizations is given in Table 1

The study of the filter media has been carried out by two independent methods (a) the laboratory determination of such filter characteristics as thickness, density, tensile strength, ash content, pressure drop across the filter at various linear velocities, and retentivity toward $03 \mu$ dioctyl phthalate derosol particles as a function of air velocity, and (b) a field or "practical determindtion of filter retentivity toward radioactive derosols existing in the atmosphere (both fission products and the smaller short-lived radon-daughter products) at several flow rates, of the effect of dust loading on aurflow, and of the relative flow and pressure drop of the various filters in the same filter system

\section{Laboratory Evaluation}

To assess the performance of a filter, the filter should be evaluated against the type and size range of patticles that will be encountered under working conditions and evaluated at the flow rate utlized by the sampler In general, it is impractical to subject filters to comprehensive tests of this nature, thus, it has been necessary to devise arbitrary methods, the results of which can be related to the actual performance of the filter While measurement of such an important factor as resistance to airflow can readily be made, other characteristics, such as rate of clogging and general serviceability, can be assessed only durıng actual exposure

A number of test methods have been developed, some of which are applicable to evaluation of the filters themselves while others pertain to evaluation of the materials from which the filters are derived At NRL a different and more exacting test was developed for use in the testing of military gas-mask filters, where the standards of protection are very much higher than those normally required for industrial filter materials This test is generally referred to as the dioctyl phthalate (DOP) test, it has been described in detall by Knudson and White (3) Instrumental parts of the DOP tester and theories of their operation have also been presented in the literature $(4,5)$
For our needs a very brief description will suffice A smoke generator is provided for producing a controlled, monodisperse liquid aerosol of DOP by condensation from the vapor state The droplets can be made extremely homogeneous at $03 \mu$ diameter with particle loadings of about 100 micrograms per liter of air Accurate measurements of smoke partucle concentration are made in a light-scattering chamber provided with a sensitive photoelectric detector The penetrometer (detector) is calibrated against the full aerosol concentration (100 percent) and against absolutely clean air ( 0 percent) Penetrdtion through a test specimen can then be read off directly in percent, with 0001 percent being the ultimate sensitivity

Under the standardized condition of testing, DOP smoke penetration measurements are made at 28 linear feet per minute (85 liters of air per minute through $100 \mathrm{~cm}^{2}$ of filter surface) To reach higher flow velocities the total flow is mantained while the filter area is reduced proportionately

Table 2 shows the resistance to aurflow for all of the filter materials evaluated in terms of the pressure drop across the filter at various linear velocities through the filter In every instance the observed pressure drop is linear with flow rate, thus indicating streamline flow through the medium The actual resistance values given should be considered as representative of the specific filter evaluated, since considerable variations were observed among different sheets of the same material, this was especially true of the so-called "chemical" filter papers

Table 3 shows the variation in filtration efficiency toward $03 \mu$ DOP aerosol as a function of the air velocity The filtration performance of the various media seems to fall into one of three separate types The first type, illustrated by IPC 1478, shows a broad plateau of relatively constant penetration with increasing velocity This is characteristic of loosely woven, lowresistance materials These filters generally exhibit a high penetration for the $03 \mu$ test aerosol The second type, illustrated by Whatman \#41 paper, shows a contınuous decrease in penetration with increasing air velocity, which is indicatıve of the tightly packed (heavly calendered), high-resistance materials The penetration of this type is usually high at the low flow rates but is considerably lower at the higher arr velocities 
TABLE 1

Identification of Air Filter Media

\begin{tabular}{|c|c|c|c|}
\hline Filter Type & Filter Designation & Manufacturer (or Distributor) & Organizations Employıng the Filter for Air Monitoring Purposes* \\
\hline \multirow[t]{14}{*}{ Cellulose } & Esparto & B O Morris, England & United Kıngdom (Atomic Energy Research Establishment)* \\
\hline & Gryksbo \#8 & Manufactured in Sweden & Denmark (Research Establıshment Riso)* \\
\hline & IPC 1478 & $\begin{array}{l}\text { Institute of Paper } \\
\text { Chemistry, USA }\end{array}$ & $\begin{array}{l}\text { United States (Defense Atomic Support Agency, } \\
\text { High-Altıtude Sampling Program)* } \\
\text { United States (Atomic Energy Commission, } \\
\text { "Ash Can" Balloon Sampling Program) }\end{array}$ \\
\hline & MSA BM-2133 & $\begin{array}{l}\text { (Mine Safety Appliances Co, } \\
\text { USA) }\end{array}$ & $\begin{array}{l}\text { Unted States Public Hedth Service (Radiation } \\
\text { Survellance Network)* }\end{array}$ \\
\hline & $S$ and $S 589 / 1$ & $\begin{array}{l}\text { Schleucher and Schuell, } \\
\text { Germany }\end{array}$ & Italy (Comitato Nazionale per L'Energia Nucleare)* \\
\hline & $S$ and $S 589 / 2$ & $\begin{array}{l}\text { Schleicher and Schuell, } \\
\text { Germany }\end{array}$ & Italy (Comitato Nazıonale per L'Energia Nucleare)* \\
\hline & $S$ and $S 2430 \%$ & $\begin{array}{l}\text { Schleicher and Schuell, } \\
\text { Germany }\end{array}$ & $\begin{array}{l}\text { Germany (Deutscher Wetterdienst)* } \\
\text { Israel (Atomic Energy Commission)* } \\
\text { Spain (Junta de Energia Nuclear) }\end{array}$ \\
\hline & Struer & Manufactured in Denmark & Denmark (Research Establishment Riso)* \\
\hline & TFA-41 & (The Staplex Co, USA) & $\begin{array}{l}\text { New Zealand (Dommon X-Ray and Radium Labordtory) } \\
\text { Belgium (Royal Meteorological Institute) }\end{array}$ \\
\hline & TFA-2133 & (The Staplex Co, USA) & New Zealand (Dominion X-Ray and Raduum Laboratory) \\
\hline & Toyo 5A & Manufactured in Japan & Japan Meteorologıcal Agency* \\
\hline & Whatman \# 1 & $\begin{array}{l}\text { W and } \mathbf{R} \text { Balston Lid, } \\
\text { England }\end{array}$ & Denmark (National Defence Research Establishment) \\
\hline & Whatman \#41 & $\begin{array}{l}\text { W and } R \text { Balston Ltd, } \\
\text { England }\end{array}$ & $\begin{array}{l}\text { Ireland (Meteorological Service) } \\
\text { Netherlands (Royal Netherlands Meteorological Institute) } \\
\text { Poland (Institute of Nuclear Research) } \\
\text { Portugal (National Meteorological Service) } \\
\text { Spain (Junta de Energia Nuclear) }\end{array}$ \\
\hline & Whatman \#541 & $\begin{array}{l}\text { W and R Balston Ltd, } \\
\text { England }\end{array}$ & $\begin{array}{l}\text { Belgium (Nuclear Energy Research Center) } \\
\text { Luxemburg (Conseil National de l'Energie Nucleaire) }\end{array}$ \\
\hline \multirow{9}{*}{$\begin{array}{l}\text { Cellulose- } \\
\text { Asbestos }\end{array}$} & Draeger & Draegerwerk, Lubeck, Germany & Norwegtan Defence Research Establishment* \\
\hline & Draeger \#6901 & Draegerwerk, Lubeck, Germany & Germany (Heidelberg University)* \\
\hline & $\mathrm{HV}-70$ & Hollingsworth and Vose, USA & Indıa (Atomıc Energy Establishment Trombay) \\
\hline & S-P bleu (HYN 75\%) & $\begin{array}{l}\text { Etablissements Schneider- } \\
\text { Poelman, France }\end{array}$ & France (Dırectıon de la Météorologie Natıonale)* \\
\hline & S-P jaune (HYN 97\%) & $\begin{array}{l}\text { Etablissements Schneider- } \\
\text { Poelman, France }\end{array}$ & France (Direction de la Meteorologie Natıonale)* \\
\hline & S-P rose (HYN 100\%) & $\begin{array}{l}\text { Etablissements Schneider- } \\
\text { Poelman, France }\end{array}$ & France (Direction de la Meteorologie Nationale)* \\
\hline & Toyo HE-10 & Manufactured in Japan & Japan Meteorologıcal Agency* \\
\hline & Type 5 & Hollingsworth and Vose, USA & US Naval Research Laboratory* \\
\hline & Type $6(\mathrm{Navy} N-15)$ & Hollingsworth and Vose, USA & $\begin{array}{l}\text { U S Naval Research I aboratory* } \\
\text { (NRL 80th Meridian Program } 1957 \text { 1962) }\end{array}$ \\
\hline $\begin{array}{l}\text { Cellulose-Glass } \\
\text { Fiber }\end{array}$ & Type $5 \mathrm{G}$ & Hollingsworth and Vose, USA & U S Naval Research Laboratory* \\
\hline Glass Fiber & $\begin{array}{l}\text { FOA-1-484 } \\
\text { Gelman Type A }\end{array}$ & $\begin{array}{l}\text { Gryksbo, Sweden } \\
\text { (Gelman Instrument Co, USA) }\end{array}$ & $\begin{array}{l}\text { Sweden (Research Institute of National Defence)* } \\
\text { _ }\end{array}$ \\
\hline
\end{tabular}

Table Continues

*Samples supplied by indicated organizations, otherwise filters were obtained from commercial sources

†Avalable only ds a narrow paper tape unsuited for this study, Carl Schleıcher of Schleicher and Schuell (Keane, New Hampshire, USA) supplied sheets of $S$ and $S 2610$ paper which was said to be the equivalent of $S$ and $S 2430$ 
TABLE I (Continued)

Identification of Air Filter Media

\begin{tabular}{|c|c|c|c|}
\hline Filter Type & Filter Desıgnation & Manufacturer (or Distributor) & Organizations Employing the Filter for Air Monitoring Purposes* \\
\hline \multirow[t]{4}{*}{ Glass Fiber } & Gelman Type E & (Gelman Instrument Co, USA) & - \\
\hline & MSA $1106 \mathrm{~B}$ & $\begin{array}{l}\text { (Mine Safety Appliances Co } \\
\text { USA) }\end{array}$ & $\begin{array}{l}\text { U S Public Health Service (National Air Sampling Network)* } \\
\text { Netherlands (Royal Netherlands Meteorological Institute) }\end{array}$ \\
\hline & TFA-69 CF & (The Staplex Co, USA) & Mexico (Comision Nacional de Energia Nuclear)* \\
\hline & Whatman GF/A & $\begin{array}{l}\text { W and } \mathbf{R} \text { Balston Ltd } \\
\text { England }\end{array}$ & $\begin{array}{l}\text { United Kıngdom (Atomıc Energy Research Establıshment)* } \\
\text { Denmark (Resedrch Establıshment Rıso) } \\
\text { Ghana (Universıty of Ghana) }\end{array}$ \\
\hline \multirow[t]{2}{*}{ Polystyrene } & Microsorban & (Gelman Instrument Co, USA) & $\begin{array}{l}\text { Canada (Radidtion Protection Division, Department of National } \\
\text { Health and Welfare)* } \\
\text { U S. Atomic Energy Commission (HASI 80th Meridian Network) } \\
\text { Austria (Bundesstaatlich Bakteriologisch-Serologische } \\
\text { Untersuchungsanstalt) }\end{array}$ \\
\hline & Delbag & Delbag Luftfilter, Germany & $\begin{array}{l}\text { U S. Air Force (Cambridge Research Laboratories)* } \\
\text { France (Direction de Metéorologie' Nationale)* }\end{array}$ \\
\hline \multirow[t]{2}{*}{ Membrane } & $\begin{array}{l}\text { Millıpore AA } \\
(08 \mu \text { pore size }) \\
\text { Polypore AM- } 1 \\
(50 \mu \text { pore size })\end{array}$ & (Gelman Instrument $\mathrm{Co}, \mathrm{USA})$ & $\begin{array}{l}\text { Varıous organizations have been reported to use "Millipore" оr } \\
\text { "membrane" filters but the particular filters were not further } \\
\text { identıfied } \\
\text { Netherlands (Royal Netherlands Meteorological Instıtute) } \\
\text { Czechoslovakia (Geophysical Institute) } \\
\text { Belgıum (Centre d'Etude de l'Energie Nucleare) }\end{array}$ \\
\hline & $\begin{array}{l}\text { Polypore AM-3 } \\
(20 \mu \text { pore size })\end{array}$ & (Gelman Instrument Co, USA) & \\
\hline
\end{tabular}

*Samples supplied by indicated organizations, otherwise filters were obtained from commercial sources

The third type, illustrated by MSA 1106B, shows a changing penetration with flow. With an increase in velocity, the penetration increases to a maximum at about $30 \mathrm{~cm}$ per sec, but as the flow rate is further increased, penetration decreases progressively. This behavior has been studied by Ramskill and Anderson (6), who attribute the various shapes of the penetration-flow performances to the influence played by the various filtration mechanisms (diffusion, inertia, inter(eption). In addition, these authors show how the character of the curves is controlled by aerosol particle size, particle density, diameter of the filter fiber, and interfiber spacing. It was determined that, in general, particles of higher density have less penetration through a given filter, especially at the higher velocities. It was also shown that, although particle shape was important, filtration performance could be predicted by using an average particle size for aggregates or irregularly shaped materials.

\section{Field Evaluation of Filter Retentivity}

The retentivity of the filters toward airborne radioactive materials was determined by means of a filter-pack technique wherein atmospheric air was drawn successively through the filter under study and then through a so-called ultimate filter (Type 6 cellulose-asbestos paper) clamped together in a suitable holder, after which the filters were separated and the radioactivity of comparable areas measured by standard $\beta$-counting techniques. Different flow rates were obtained by employing three different positive-displacement blowers driven by constant-speed electric motors: (a) a Leiman Model 29-6 blower driven by a 3-hp motor and having a capacity of about 20 cfm (cubic feet per minute) through a 2-1/2-in.diameter Type 6 paper (the backup or final filter employed in these studies), (b) a Roots-Connersville Rotary-Positive blower (Type AF-24) driven by a 1-hp motor and having a capacity of about $19 \mathrm{cfm}$ through a 4-in.-diameter Type 6 paper, and (c) a graphite vane vacuum pump (M-D 
TABLE 2

Relationship of Pressure Drop to Flow Rate for Various Air Filter Media

\begin{tabular}{|c|c|c|c|c|c|c|c|}
\hline \multirow{2}{*}{ Filter and Type } & \multicolumn{7}{|c|}{ Pressure Drop (mm Hg) dt Various Flow Rates } \\
\hline & $\begin{array}{c}35 \\
(\mathrm{~cm} / \mathrm{sec})\end{array}$ & $\begin{array}{c}53 \\
(\mathrm{~cm} / \mathrm{sec})\end{array}$ & $\begin{array}{c}71 \\
(\mathrm{~cm} / \mathrm{sec})\end{array}$ & $\begin{array}{c}106 \\
(\mathrm{~cm} / \mathrm{sec})\end{array}$ & $\begin{array}{c}141 \\
(\mathrm{~cm} / \mathrm{sec})\end{array}$ & $\begin{array}{c}211 \\
(\mathrm{~cm} / \mathrm{sec})\end{array}$ & $\begin{array}{c}283 \\
(\mathrm{~cm} / \mathrm{sec})\end{array}$ \\
\hline \multicolumn{8}{|l|}{ Cellulose } \\
\hline Esparto & 10 & 16 & 20 & 30 & 41 & 60 & 81 \\
\hline Gryksbo \#8 & 25 & 38 & 51 & 77 & 100 & 155 & 202 \\
\hline IPC 1478 & 1 & 1.5 & 2 & 3 & 3.5 & 5.5 & 7.0 \\
\hline MSA BM-2133 & 6 & 8 & 11 & 17 & 22 & 33 & 44 \\
\hline$S$ and $S 589 / 1$ & 18 & 27 & 37 & 56 & 74 & 112 & 149 \\
\hline$S$ and $S 589 / 2$ & 29 & 48 & 67 & 106 & 134 & 213 & 270 \\
\hline$S$ and $S 2610$ & 1 & 2 & 3 & 5 & 7 & 10 & 13 \\
\hline Struer & 6 & 9 & 12 & 18 & 24 & 36 & 48 \\
\hline TFA-41 & 23 & 40 & 48 & 81 & 95 & 160 & 190 \\
\hline TFA-2133 & 5 & 8 & 12 & 16 & 25 & 33 & 51 \\
\hline Toyo 5A & 15 & 23 & 30 & 45 & 61 & 92 & 123 \\
\hline Whatman \#1 & 60 & 86 & 116 & 175 & 235 & 350 & 468 \\
\hline Whatman \#41 & 24 & 36 & 48 & 72 & 95 & 146 & 194 \\
\hline Whatman \#541 & 20 & 30 & 41 & 61 & 82 & 123 & 163 \\
\hline \multicolumn{8}{|l|}{ Cellulose-Asbestos. } \\
\hline Draeger & 34 & 50 & 68 & 102 & 138 & 205 & 278 \\
\hline Draeger \#6901 & 56 & 82 & 110 & 164 & 222 & 328 & 445 \\
\hline $\mathrm{HV}-70$ & 44 & 64 & 87 & 127 & 172 & 254 & 343 \\
\hline S-P bleu & 6 & 9 & 12 & 18 & 24 & 36 & 49 \\
\hline S-P jaune & 15 & 21 & 29 & 44 & 57 & 86 & 114 \\
\hline S-P rose & 38 & 57 & 75 & 112 & 148 & 225 & 290 \\
\hline Toyo HE-10 & 59 & 87 & 117 & 171 & 235 & 340 & 470 \\
\hline Type 5 & 3 & 5 & 7 & 10 & 14 & 20 & 27 \\
\hline Type 6 (Navy N-15) & 22 & 32 & 43 & 67 & 86 & 130 & 192 \\
\hline \multicolumn{8}{|l|}{ Cellulose-Glass } \\
\hline Type 5G & 3 & 5 & 7 & 10 & 14 & 21 & 28 \\
\hline \multicolumn{8}{|l|}{ Glass Fiber } \\
\hline FOA-1-484 & 18 & 30 & 37 & 61 & 80 & 126 & 168 \\
\hline Gelman Type A & 23 & 33 & 43 & 65 & 85 & 129 & 170 \\
\hline Gelman Type E & 19 & 28 & 38 & 57 & 76 & 114 & 150 \\
\hline Hus lbuit $934 \mathrm{AH}$ & 25 & 37 & 50 & 74 & 99 & 150 & 198 \\
\hline MSA $1106 \mathrm{~B}$ & 20 & 30 & 40 & 61 & 79 & 120 & 160 \\
\hline TFA-69GF & 20 & 27 & 39 & 55 & 80 & 110 & 158 \\
\hline Whatman GF/A & 20 & 29 & 40 & 60 & 78 & 118 & 157 \\
\hline \multicolumn{8}{|l|}{ Polystyrene } \\
\hline Microsorban & 14 & 21 & 29 & 43 & 57 & 85 & 112 \\
\hline Delbag & 31 & 44 & 60 & 89 & 118 & 176 & 235 \\
\hline \multicolumn{8}{|l|}{ Membrane } \\
\hline Millipore AA & 98 & 142 & 195 & 285 & 388 & 570 & - \\
\hline Polypore AM-1 & 16 & 23 & 31 & 46 & 62 & 95 & 127 \\
\hline Polypore AM-3 & 56 & 84 & 117 & 190 & 237 & 380 & 470 \\
\hline
\end{tabular}


TABLE 3

DOP Smoke Penetration of Varıous Filter Media as a Function of Aır Velocity

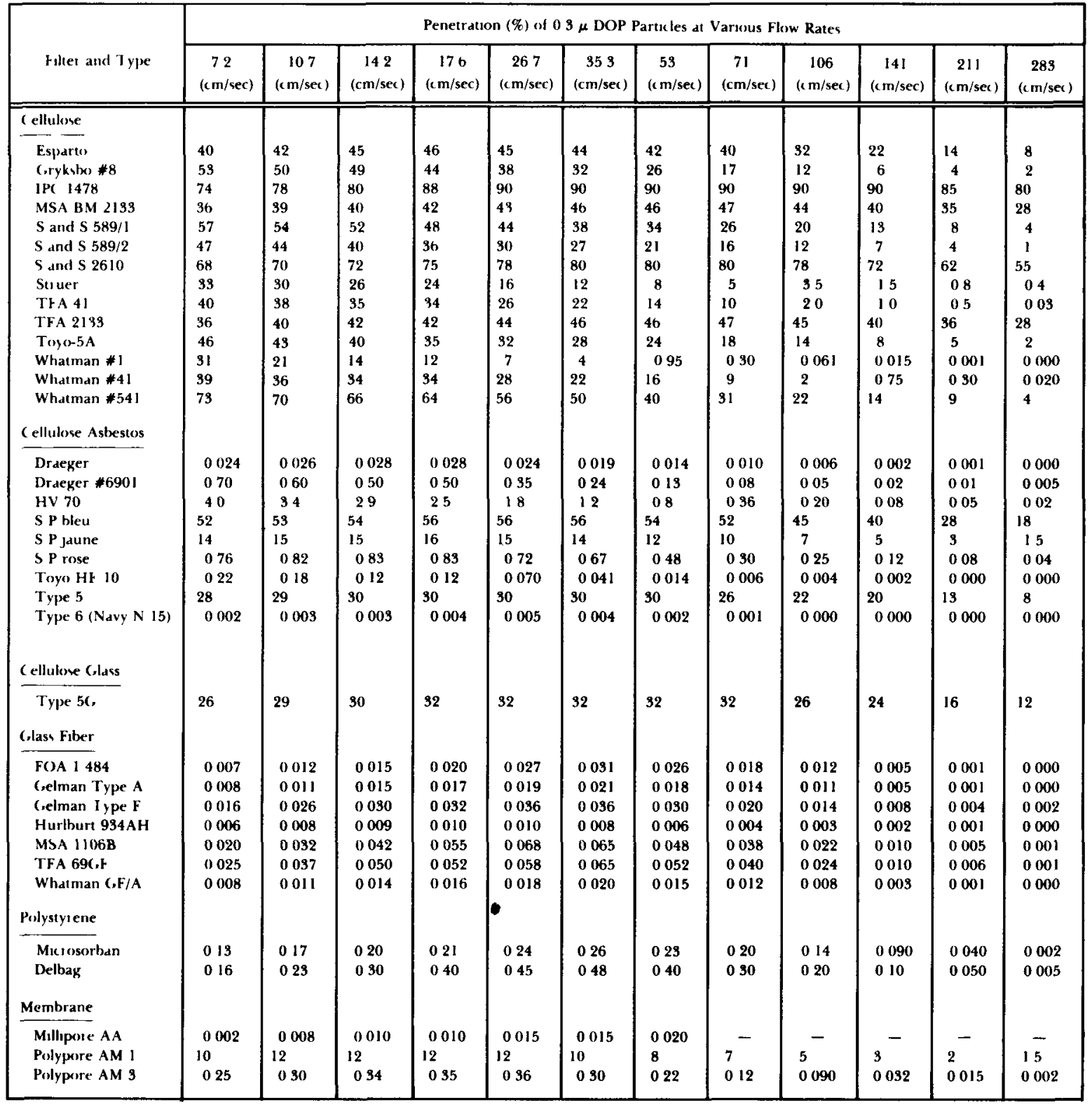


Blowers, Inc, Model 50-DA-3FS) driven by a 3/4-hp motor and having a capacity of about $8 \mathrm{cfm}$ through a 4-in -diameter Type 6 filter Aurflow as a function of the pressure drop across the filter was determined by calibration against the same flow meter, actual flow rates were monitored by observing the corresponding pressure changes with time

Fission product radioactivity was collected by exposures of 8 to 72 hours depending on the work schedule, the quantity of radioactivity in the air, and the rate of dust loading of the filter Dust loading of the hard-surfaced papers, particularly those with low initial flow rates, was often a limitation in securing a suitable sample, the resulting increased pressure drop across the filter caused the blower and motor to become overloaded and to overheat with the result that the collection was terminated The flow rate was determined from the average of the initial and final flow rates At the end of the collection period the filters were separated, placed in glassine envelopes, and stored for a minımum of 7 days to permit decay of the interfering natural radioactivity The filters were counted for $\beta$ activity in succession on the same counter using sufficiently long counting times ( 1 to 18 hours) to give reasonable statistical accuracy Radioactive decay during this period was negligible and the relative counting rates did not need correction for decay or other variables (selfabsorption of the $\beta$ activity by the filter was neglected) A comparison of the activity of the initial filter with the total activity collected by the two filters was a measure of the retentivity of the initial filter

Radon-daughter products $(\mathrm{RaB}+\mathrm{C})$ with their short effective half-lives were collected through a short sampling period (about 30 minutes) during which time about 50 percent of their equilıbrium value was obtained Dust clogging presented no problem in these short collections Countıng was started immediately after termination of the collection using either (d) the preferred procedure, which involved counting the filters simultaneously for $\mathbf{4 5}$ minutes on two identical $\beta$-counting units that had been intercalibrated, or (b) the original procedure, which consisted of counting the final filter for tive successive 5-minute periods after which the initial (top) filter was counted for five or more 5-minute periods The latter procedure was employed when there was only a limited number of counters avalable for use in this study The results were plotted on semulog paper and the counting rates were extrapolated to a common time, for example, the midpoint of the counting period of the backup filter The efficiency of retention was determined by a comparison of the activities on the two filters at that time Often the $\mathrm{RaB}+\mathrm{C}$ activity was so large that the longerlived thoron-daughter products and fission products that were also collected could be ignored When the natural activity was lower, a second count after 5 hours was made to determine the extent of correction required for these longerlived isotopes Since generally only a small fraction of the fission products penetrated to the second filter, the corrections were of minor importance On many occasions during the period March through May (1963), natural dctivity levels were so low that no satisfactory collections could be made

The statistical variation (standard deviation) of the counting rates was determined from the expression $\sigma=\sqrt{N} / N$, where $N$ is the total number of counts The degree of accuracy varied with the quantity of activity collected, $\sigma$ was generally quite low for the fission product collections, except for some of the hard-surfaced papers which tended to become clogged before the desired size sample was obtained With the natural radioactivity, sample size was determined both by the daly variations in the $\mathrm{RaB}+\mathrm{C}$ content of the air and by the flow characteristic of the papers, these factors, combined with the short counting times, resulted in larger standard deviations in the medsured retentivity for these determinations

The measurements of the retentivity of natural activity $(\mathrm{RaB}+\mathrm{C})$ and of fission products by the various filters are summarized in Tables 4 and 5 In general, only the two series of measurements having the highest statistical significance have been included, those measurements which have been omitted were in essential agreement with those listed Collections made during periods of ramfall have been omitted, because on several occasions activity was observed to have been transferred from the top to the bottom filter through the solvent action of the collected water droplets The wide range of retentivity values that may be noted in several cases is due to either or both of two factors (a) nonuniformity in the 
I ABI +4

Measured Retentivits of All Filters for Natural Radiodatuve Aerosols (RaB + ( ) in the Atmospheie

\begin{tabular}{|c|c|c|c|c|c|c|c|c|c|}
\hline \multirow{2}{*}{$\begin{array}{l}\text { Filter } \\
\text { lype }\end{array}$} & \multirow[b]{2}{*}{ Filtel } & \multirow{2}{*}{$\begin{array}{l}\text { Date of } \\
\text { collection }\end{array}$} & \multirow[b]{2}{*}{ Wedther } & \multicolumn{2}{|c|}{ Unit $\mathbf{A}$} & \multicolumn{2}{|c|}{ Unt B } & \multicolumn{2}{|c|}{ Unut $C$} \\
\hline & & & & $\begin{array}{c}\text { Air Velocity } \\
(\mathrm{cm} / \mathrm{sec})\end{array}$ & $\begin{array}{l}\text { Retention } \\
(\%)\end{array}$ & $\begin{array}{c}\text { Air Velocity } \\
\text { (cm/sec) }\end{array}$ & $\begin{array}{l}\text { Retention } \\
(\%)\end{array}$ & $\begin{array}{c}\text { Air Velocily } \\
\text { (cm/sec) }\end{array}$ & $\begin{array}{c}\text { Retention } \\
(\%)\end{array}$ \\
\hline \multirow[t]{28}{*}{ c cllulose } & Fsparto & $11-8-62$ & Cloudy & 60 & $595 \pm 10$ & 139 & $634 \pm 05$ & 314 & $883 \pm 02$ \\
\hline & & $2-6-63$ & ( lear & 60) & $501 \pm 14$ & 136 & $744 \pm 05$ & 326 & $879 \pm 02$ \\
\hline & cryksbo \#8 & 4-1963 & Cloudy & 58 & $732 \pm 11$ & 118 & $841 \pm 05$ & 204 & $921 \pm 02$ \\
\hline & IPC 1478 & $10-22-62$ & C lear & 62 & $88 \pm 09$ & 151 & $131 \pm 06$ & 338 & $219 \pm 03$ \\
\hline & & $3-1-63$ & ( loudy & 61 & $67 \pm 10$ & 154 & $106 \pm 05$ & 373 & $241 \pm 04$ \\
\hline & MSA BM-2133 & $1022-62$ & C ledr & 64 & $849 \pm 17$ & 139 & $879 \pm 06$ & - & - \\
\hline & (carbon side up) & $10-2462$ & - & - & - & 141 & $781 \pm 08$ & 341 & $799 \pm 05$ \\
\hline & & 21463 & Cledi & 61 & $814 \pm 12$ & 146 & $844 \pm 06$ & 347 & $86 b \pm 03$ \\
\hline & $S$ and $S 589 / 1$ & $10 \quad 362$ & Cloudy & 59 & $810 \pm 08$ & 127 & $921 \pm 04$ & 236 & $973 \pm 01$ \\
\hline & & $2-7-63$ & Haly & 58 & $844 \pm 05$ & 124 & $939 \pm 02$ & 235 & $972 \pm 01$ \\
\hline & $S$ and $S 589 / 2$ & $103-62$ & ( loudy & 56 & $881 \pm 05$ & 111 & $936 \pm 03$ & 174 & $991 \pm 01$ \\
\hline & & $2-27-63$ & ( loudy & 58 & $747 \pm 16$ & 109 & $859 \pm 09$ & 197 & $955 \pm 04$ \\
\hline & $S$ and $S 2610$ & 111662 & 一 & 61 & $202 \pm 08$ & - & - & 347 & $607 \pm 03$ \\
\hline & & $11-16-62$ & - & - & - & 146 & $329 \pm 06$ & 342 & $688 \pm 03$ \\
\hline & Situes & 5363 & ( lear & 53 & $953 \pm 06$ & 88 & $990 \pm 04$ & 129 & $993 \pm 02$ \\
\hline & [ $\mathbf{A} \wedge-4$ ] & 92063 & ( lear & 57 & $905 \pm 03$ & 128 & $958 \pm 02$ & 240 & $987 \pm 01$ \\
\hline & & 10963 & C ledi & 57 & $657 \pm 09$ & 129 & $788 \pm 07$ & 232 & $923 \pm 03$ \\
\hline & & 101063 & $\mathrm{Ha} / y$ & 58 & $815 \pm 05$ & 123 & $946 \pm 02$ & 211 & $992 \pm 01$ \\
\hline & 1 HA 2133 & $10-9-63$ & C lodi & 60) & $794 \pm 07$ & 145 & $722 \pm 07$ & 327 & $746 \pm 03$ \\
\hline & (carbon side up)) & $10-10-63$ & $\mathrm{H}_{d / y}$ & 54 & $754 \pm 05$ & 145 & $799 \pm 04$ & 322 & $898 \pm 02$ \\
\hline & $10 y 05 \mathrm{~A}$ & $119-62$ & C loudy & 59 & $811 \pm 07$ & 125 & $914 \pm 04$ & 239 & $975 \pm 02$ \\
\hline & & $4-23-6^{3}$ & ( loud) & 60) & $778 \pm 22$ & 129 & $916 \pm 08$ & 259 & $968 \pm 04$ \\
\hline & What man \#I & $34-63$ & (leal & 50 & $944 \pm 12$ & 81 & $965 \pm 07$ & 123 & $979 \pm 04$ \\
\hline & & $5-16-63$ & Cloudy & 52 & $901 \pm 07$ & 82 & $969 \pm 04$ & 123 & $989 \pm 02$ \\
\hline & Whatman \#4I & $1011-62$ & ( lear & 57 & $822 \pm 08$ & 113 & $927 \pm 05$ & 196 & $983 \pm 02$ \\
\hline & & $2-2763$ & C loudy & 59 & $690 \pm 18$ & 123 & $861 \pm 07$ & 227 & $937 \pm 04$ \\
\hline & Whatman \#541 & 111462 & Clear & 59 & $636 \pm 14$ & 122 & $824 \pm 08$ & 225 & $881 \pm 03$ \\
\hline & & $4-3-63$ & ( lear & 59 & $660 \pm 11$ & 126 & $788 \pm 05$ & 218 & $848 \pm 03$ \\
\hline \multirow{4}{*}{$\begin{array}{l}\text { C cllulose- } \\
\text { Asbcsios }\end{array}$} & Diagger & $4-363$ & Cledl & 56 & $1012 \pm 06$ & 106 & $999 \pm 03$ & 188 & $100) 1 \pm 02$ \\
\hline & & $4-29-63$ & Cledl & 56 & $1003 \pm 14$ & 108 & $100) 5 \pm 06$ & 184 & $1005 \pm 03$ \\
\hline & Di acgor \#6901 & $5-3-63$ & ( ledi) & 53 & $1016 \pm 19$ & 112 & $1009 \pm 08$ & 148 & $1006 \pm 03$ \\
\hline & & $5-22-63$ & Cleat & 52 & $1006 \pm 06$ & 85 & $1005 \pm 05$ & 152 & $1000 \pm 02$ \\
\hline
\end{tabular}

(1 able (onturues) 
TABle 4 (Contınued)

Measured Retentıvity of An Filters for Natural Radıactive Aerosols $(\mathrm{RaB}+\mathrm{C})$ in the Atmosphere

\begin{tabular}{|c|c|c|c|c|c|c|c|c|c|}
\hline \multirow[b]{2}{*}{$\begin{array}{l}\text { Filter } \\
\text { Type }\end{array}$} & \multirow[b]{2}{*}{ Filter } & \multirow[b]{2}{*}{$\begin{array}{l}\text { Date of } \\
\text { collection }\end{array}$} & \multirow[b]{2}{*}{ Weather } & \multicolumn{2}{|c|}{ Unt A } & \multicolumn{2}{|c|}{ Unit B } & \multicolumn{2}{|c|}{ Unit $C$} \\
\hline & & & & $\begin{array}{c}\text { An Velocity } \\
(\mathrm{cm} / \mathrm{sec})\end{array}$ & $\begin{array}{c}\text { Retention } \\
(\%)\end{array}$ & $\begin{array}{c}\text { Air Velocity } \\
(\mathrm{cm} / \mathrm{sec})\end{array}$ & $\begin{array}{c}\text { Retention } \\
(\%)\end{array}$ & $\begin{array}{c}\text { Air Velocity } \\
(\mathrm{cm} / \mathrm{sec})\end{array}$ & $\begin{array}{l}\text { Retention } \\
(\%)\end{array}$ \\
\hline \multirow{7}{*}{$\begin{array}{l}\text { Cellulose } \\
\text { Asbestos } \\
\text { (Cont d) }\end{array}$} & HV-70 & $\begin{array}{l}2-7-63 \\
516-63\end{array}$ & $\begin{array}{l}\text { Hazy } \\
\text { Cloudy }\end{array}$ & $\begin{array}{l}55 \\
55\end{array}$ & $\begin{array}{l}987 \pm 04 \\
984 \pm 07\end{array}$ & $\begin{array}{l}103 \\
102\end{array}$ & $\begin{array}{r}998 \pm 02 \\
1002 \pm 03\end{array}$ & $\begin{array}{l}191 \\
183\end{array}$ & $\begin{array}{l}998 \pm 01 \\
995 \pm 02\end{array}$ \\
\hline & S-P bleu & $\begin{array}{l}5263 \\
5-6-63\end{array}$ & $\begin{array}{l}\text { Clear } \\
\text { Cloudy }\end{array}$ & $\begin{array}{l}61 \\
61\end{array}$ & $\begin{array}{l}412 \pm 46 \\
468 \pm 18\end{array}$ & $\begin{array}{l}139 \\
141\end{array}$ & $\begin{array}{l}510 \pm 26 \\
589 \pm 08\end{array}$ & $\begin{array}{l}310 \\
309\end{array}$ & $\begin{array}{l}727 \pm 10 \\
805 \pm 04\end{array}$ \\
\hline & S-P jaune & $\begin{array}{l}5-10-63 \\
5-17-63\end{array}$ & Clear & $\begin{array}{l}60 \\
59\end{array}$ & $\begin{array}{l}827 \pm 07 \\
789+15\end{array}$ & $\begin{array}{l}125 \\
131\end{array}$ & $\begin{array}{l}890 \pm 03 \\
995+06\end{array}$ & $\begin{array}{l}259 \\
270\end{array}$ & $\begin{array}{l}956 \pm 02 \\
975+03\end{array}$ \\
\hline & S Prose & $\begin{array}{l}4-17-63 \\
5-3-63\end{array}$ & $\begin{array}{l}\text { Cledr } \\
\text { Cledı }\end{array}$ & $\begin{array}{l}56 \\
57\end{array}$ & $\begin{array}{l}999 \pm 09 \\
984 \pm 03\end{array}$ & $\begin{array}{l}107 \\
103\end{array}$ & $\begin{array}{l}990 \pm 05 \\
994 \pm 02\end{array}$ & $\begin{array}{l}197 \\
191\end{array}$ & $\begin{array}{r}998 \pm 03 \\
1000 \pm 01\end{array}$ \\
\hline & Toyo HE-10 & $\begin{array}{l}10-262 \\
3-4-63\end{array}$ & Clear & $\begin{array}{l}57 \\
53\end{array}$ & $\mid \begin{array}{ll}100 & 1 \pm 04 \\
101 & 7 \pm 1\end{array}$ & $\begin{array}{l}88 \\
74\end{array}$ & $\begin{array}{l}998 \pm 03 \\
993+06\end{array}$ & $\begin{array}{l}151 \\
151\end{array}$ & $\begin{array}{l}1000 \pm 02 \\
1002 \pm 09\end{array}$ \\
\hline & Type 5 & $\begin{array}{l}101262 \\
10-19-62\end{array}$ & $\begin{array}{l}\text { Clear } \\
\text { Clear }\end{array}$ & $\overline{61}$ & $66 \overline{1 \pm 07}$ & $\begin{array}{l}148 \\
149\end{array}$ & $\begin{array}{l}738 \pm 04 \\
731 \pm 03\end{array}$ & $\begin{array}{l}327 \\
336\end{array}$ & $\begin{array}{l}860 \pm 02 \\
855 \pm 02\end{array}$ \\
\hline & $\begin{array}{l}\text { Type } 6 \\
\text { (Navy N-15) }\end{array}$ & $\begin{array}{l}10-1-62 \\
3-8-63 \\
5-20-63\end{array}$ & $\begin{array}{l}\text { Hazy } \\
\text { Clear } \\
\text { C loudy }\end{array}$ & $\begin{array}{l}58 \\
58 \\
58\end{array}$ & $\mid \begin{array}{lll}100 & 1 \pm 0 & 3 \\
101 & 3 \pm 1 & 4 \\
100 & 1 \pm 0 & 5\end{array}$ & $\begin{array}{c}- \\
120 \\
119\end{array}$ & $\begin{array}{c}- \\
999 \pm 06 \\
994 \pm 03\end{array}$ & $\begin{array}{l}233 \\
259 \\
248\end{array}$ & $\mid \begin{array}{lll}100 & 0 \pm 0 & 0 \\
100 & 1 \pm 0 & 3 \\
100 & 0 \pm 0 & 1\end{array}$ \\
\hline $\begin{array}{l}\text { Cellulose- } \\
\text { Glass Fibeı }\end{array}$ & Type 56, & $\begin{array}{l}2-20-63 \\
3-1-63\end{array}$ & $\begin{array}{l}\text { Clear } \\
\text { Cloudy }\end{array}$ & $\begin{array}{l}61 \\
61\end{array}$ & $\begin{array}{l}596 \pm 14 \\
636 \pm 17\end{array}$ & $\begin{array}{l}150 \\
146\end{array}$ & $\begin{array}{l}646 \pm 06 \\
699 \pm 08\end{array}$ & $\begin{array}{l}342 \\
344\end{array}$ & $\begin{array}{l}740 \pm 04 \\
811 \pm 04\end{array}$ \\
\hline \multirow[t]{7}{*}{ Glass Fiber } & FOA-1-484 & $10-3-63$ & ( lear & 58 & $1001 \pm 04$ & 131 & $1001 \pm 02$ & 270 & $999 \pm 01$ \\
\hline & Gelman Type A & $4-22-63$ & Cloudy & 58 & $1009 \pm 23$ & 123 & $1000 \pm 06$ & 235 & $998 \pm 03$ \\
\hline & Gelman Type E & $4-19-63$ & ( ledr & 59 & $998 \pm 05$ & 123 & $995 \pm 02$ & 248 & $999 \pm 01$ \\
\hline & Hurlburt $934 \mathrm{AH}$ & $\begin{array}{l}10-262 \\
3-7-63\end{array}$ & $\begin{array}{l}\text { Clear } \\
\text { C leas }\end{array}$ & $\begin{array}{l}57 \\
58\end{array}$ & 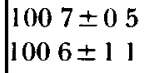 & $\begin{array}{l}120 \\
118\end{array}$ & $\begin{array}{r}1000 \pm 02 \\
999 \pm 07\end{array}$ & $\begin{array}{l}209 \\
237\end{array}$ & 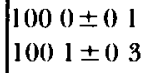 \\
\hline & MSA $1106 B$ & $\begin{array}{l}9-28-62 \\
5-20-63\end{array}$ & $\begin{array}{l}\text { Cledı } \\
\text { Cloudy }\end{array}$ & $\begin{array}{l}58 \\
59\end{array}$ & $\begin{array}{r}998 \pm 05 \\
1001 \pm 07\end{array}$ & $\begin{array}{l}130 \\
124\end{array}$ & $\begin{array}{r}994 \pm 03 \\
1000 \pm 03\end{array}$ & $\begin{array}{l}250 \\
261\end{array}$ & $\begin{array}{l}997 \pm 01 \\
999 \pm 01\end{array}$ \\
\hline & TFA-69GF & $9-20-63$ & Cleaı & 57 & $997 \pm 02$ & 130 & $998 \pm 01$ & 258 & $999 \pm 01$ \\
\hline & Whatman G,F/A & $\begin{array}{l}10-5-62 \\
4-17-63\end{array}$ & $\begin{array}{l}\text { C loudy } \\
\text { ( loudy }\end{array}$ & $\begin{array}{l}59 \\
59\end{array}$ & $\mid \begin{array}{llll}100 & 8 & \pm 1 & 0 \\
101 & 1 & \pm 0 & 9\end{array}$ & $\begin{array}{l}126 \\
125\end{array}$ & $\begin{array}{l}993 \pm 03 \\
994 \pm 05\end{array}$ & $\begin{array}{l}259 \\
254\end{array}$ & 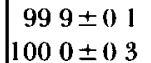 \\
\hline \multirow[t]{2}{*}{ Polystyıene } & Microsorban & $\begin{array}{l}4-4-63 \\
5-10-63\end{array}$ & $\begin{array}{l}\text { Clear } \\
\text { Clear }\end{array}$ & $\begin{array}{l}58 \\
59\end{array}$ & $\begin{array}{l}985 \pm 09 \\
956 \pm 07\end{array}$ & $\begin{array}{l}123 \\
136\end{array}$ & $\begin{array}{l}981 \pm 06 \\
948 \pm 04\end{array}$ & $\begin{array}{l}272 \\
259\end{array}$ & $\begin{array}{l}983 \pm 03 \\
984 \pm 01\end{array}$ \\
\hline & Delbag (France) & $\begin{array}{l}4-8-63 \\
5 \quad 7-63\end{array}$ & $\begin{array}{l}\text { Clear } \\
\text { Clear }\end{array}$ & $\begin{array}{l}57 \\
55\end{array}$ & $\begin{array}{lll}100 & 0 \pm 3 & 2 \\
102 & 0 \pm 2 & 8\end{array}$ & $\begin{array}{l}123 \\
119\end{array}$ & $\begin{array}{l}954 \pm 09 \\
976 \pm 13\end{array}$ & $\begin{array}{l}232 \\
216\end{array}$ & $\begin{array}{l}994 \pm 04 \\
984 \pm 06\end{array}$ \\
\hline \multirow[t]{3}{*}{ Membrane } & Millipore AA & $\begin{array}{l}2-6-63 \\
4-26-63\end{array}$ & $\begin{array}{l}\text { Clear } \\
\text { ( lear }\end{array}$ & $\begin{array}{l}45 \\
47\end{array}$ & $\begin{array}{rl}1001 \pm 0 & 8 \\
985 \pm 1 & \end{array}$ & $\begin{array}{l}74 \\
67\end{array}$ & $\begin{array}{r}996 \pm 04 \\
1017 \pm 10\end{array}$ & $\begin{array}{r}117 \\
91\end{array}$ & $\begin{array}{r}997 \pm 02 \\
1002 \pm 05\end{array}$ \\
\hline & Polypore AM-1 & $\begin{array}{l}9-24-62 \\
2-13-63\end{array}$ & $\begin{array}{l}\text { Clear } \\
\text { Clear }\end{array}$ & $\begin{array}{l}59 \\
60\end{array}$ & $\begin{array}{l}853 \pm 06 \\
805 \pm 22\end{array}$ & $\begin{array}{l}132 \\
130\end{array}$ & $\begin{array}{l}917 \pm 04 \\
918 \pm 07\end{array}$ & $\begin{array}{l}270 \\
275\end{array}$ & $\begin{array}{l}956 \pm 02 \\
956 \pm 03\end{array}$ \\
\hline & Polypore AM-3 & $\begin{array}{l}9-24-62 \\
2-13-63\end{array}$ & $\begin{array}{l}\text { Clear } \\
\text { ( lear }\end{array}$ & $\begin{array}{l}56 \\
56\end{array}$ & $\begin{array}{l}993 \pm 02 \\
988 \pm 22\end{array}$ & $\overline{113}$ & $\begin{array}{c}- \\
994 \pm 07\end{array}$ & $\begin{array}{l}165 \\
224\end{array}$ & $\begin{array}{l}995 \pm 02 \\
997 \pm 03\end{array}$ \\
\hline
\end{tabular}


TABLE 5

Measured Retentivity of Air Filters for Airborne Fission Products

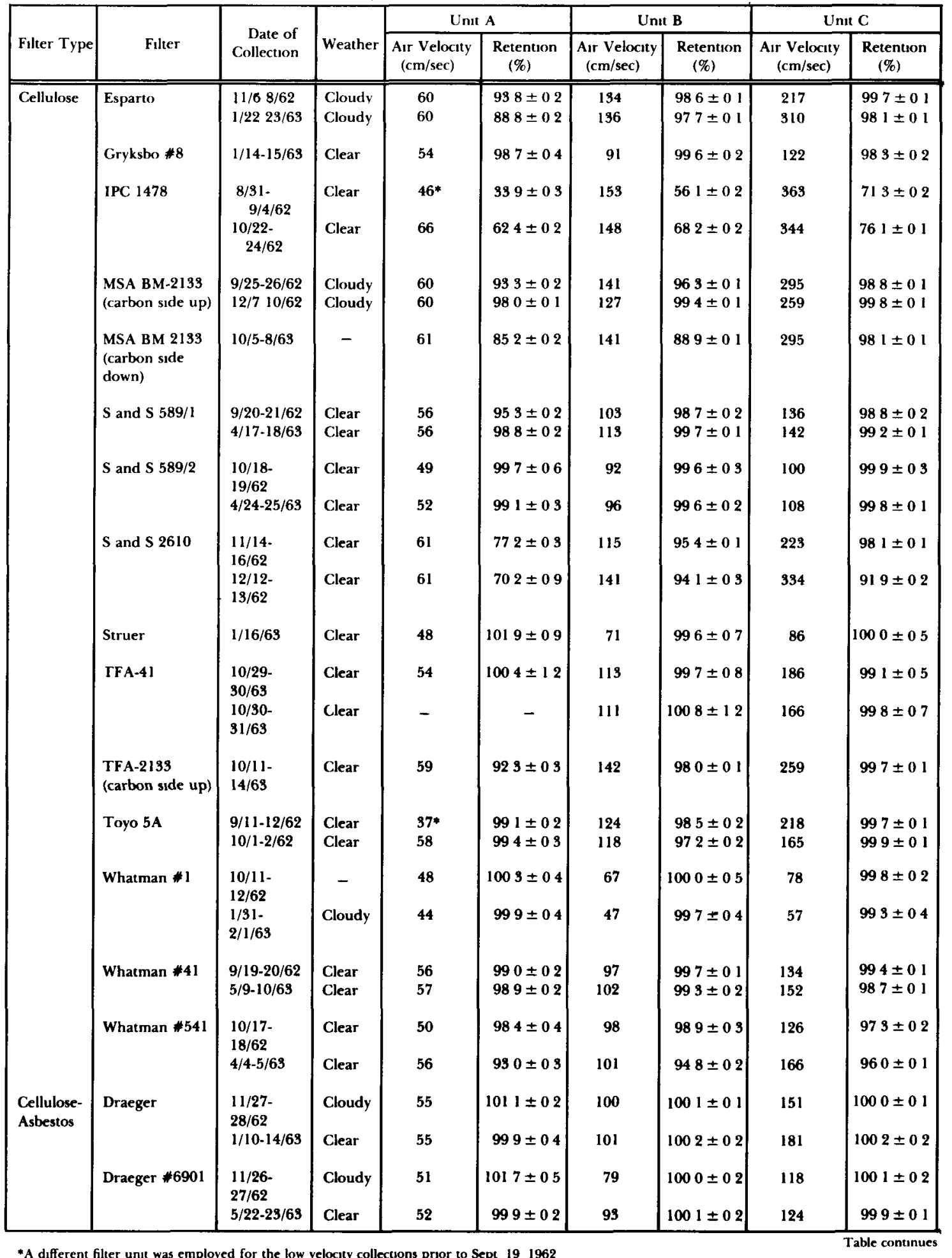


TABLE 5 (Continued)

Measured Retentivity of Air Filters for Airborne Fission Products

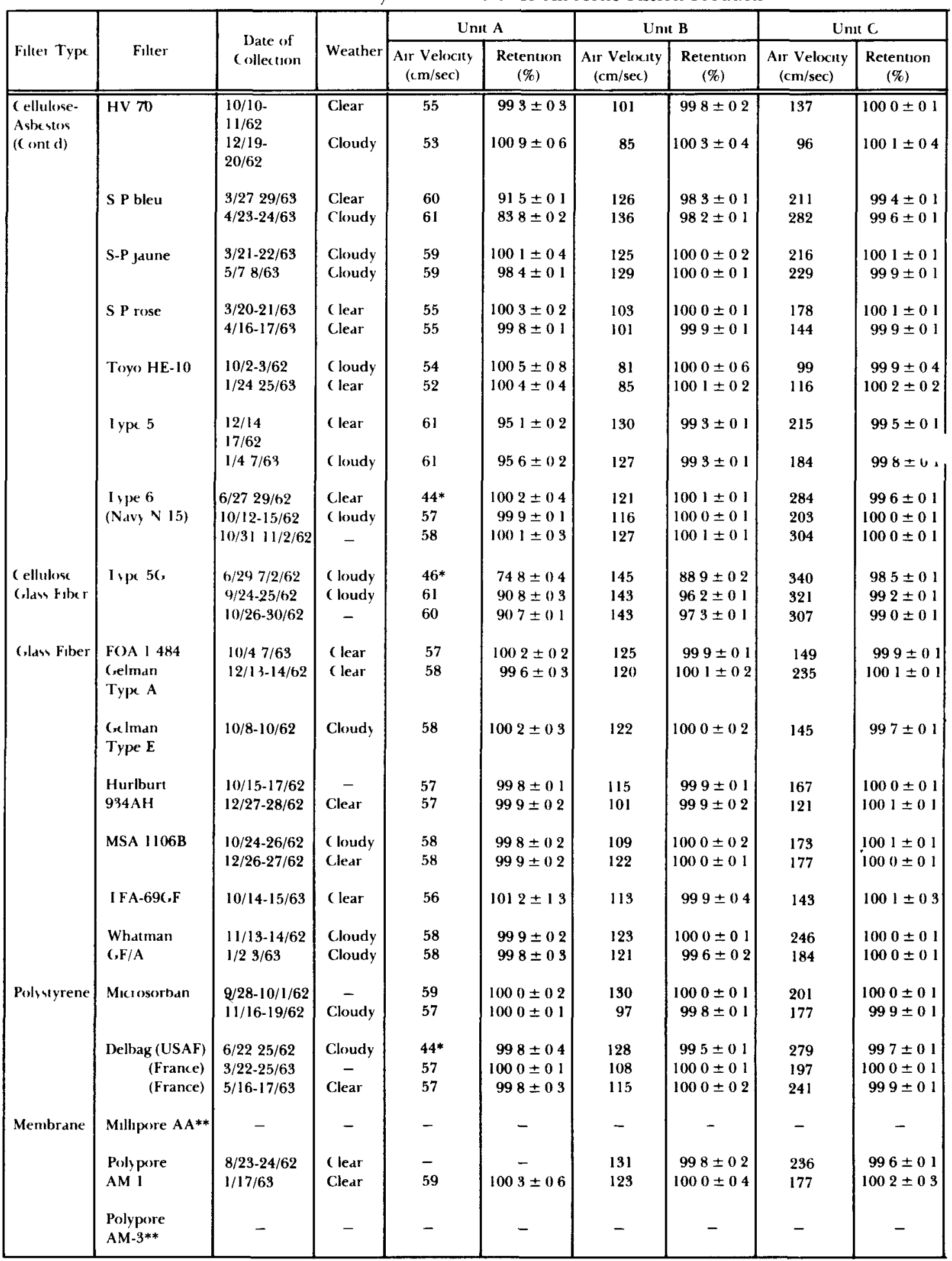

*A different filter unit was employed for the lon velocity collections prior to Sept 191962

**Flow resistance too, high for long collections to be made retentivity for tission pioducts inferred from RaBC measurements to be essentially $100 \%$ 
filter media and (b) significant day-to-day differences in the size distribution of particles with which the airborne radioactivity was associated. The latter led to the undertaking of another study involving the use of packs of three or more filters as a means of determining the particle size distribution of airborne radioactivity (7). The effective size of fission-product particulate matter decreased steadily from January through May (1963), after which time the size appeared to remain fairly constant.

\section{Field Evaluation of Other Filter Characteristics}

Filters of each type were selected at random from the available supply and used for the determination of some of the physical characteristics of the filter material. While the number available was not sufficient to categorize the filter rigorously, it was sufficient to indicate the general behavior of filters from this source. This information is presented in Table 6.

The filters were weighed on an analytical balance and an average weight $\left(\mathrm{mg} / \mathrm{cm}^{2}\right)$ was calculated for each material. Measurements of filter thickness (caliper) were made by standard procedures used in the paper industry. The ash contents were determined by igniting one or more of the weighed samples of each material at $750^{\circ} \mathrm{C}$ in a muffle furnace for an hour and then weighing the residue. In order to obtain a quantitative estimate of the ruggedness of the various filters, the average tensile strength was determined by measurement of several 1-inchwide strips of each material by use of an Instron Tensile Testing Machine; the rate of extension was 0.5 in. per minute, in accord with accepted practice.

The airflow and associated pressure drop across a 4-in.-diameter filter (effective area 60.0 $\mathrm{cm}^{2}$ ) were determined for three of the filters of each type (including the heaviest and lightest of those weighed) with a Roots-Connersville blower unit (Type AF-24) operated at $1250 \mathrm{rpm}$. The flow was determined by a Fischer and Porter flowmeter (range 0 to $55 \mathrm{cfm}$ ) and the pressure was determined by a bellows-type pressure gage (range 0 to $30 \mathrm{~cm} \mathrm{Hg}$ ). The relationship between airflow and pressure drop (vacuum) across the filter, which is characteristic of the blower used, is shown in Fig. 1. The relative positions which the various filters would assume along this curve are indicated by the average values obtained for each filter medium. For a given filter material no direct relationship between filter weight and flow characteristics was apparent.

The effect of dust loading on the flow rate through the filter was determined by exposing filters in groups of three to five in separate positivedisplacement blower units while measuring the pressure across the filter (convertible to flow rate) as a function of time. Since the atmospheric dust loading varies widely both daily and seasonally, one filter of each group was used as a standard to normalize the varying dust loadings to an "average" day; Gelman Type A glass fiber paper was selected as the reference on the basis of availability and because it generally underwent a readily measurable change in flow during an 8-hour period. For long collection periods, Type 5G cellulose-glass fiber paper was employed as a standard because of its slower rate of clogging; Whatman \# 1 paper was used as a secondary standard when faster clogging filters were being evaluated.

The percent change in flow of each filter was compared with the volume of air filtered (in $\mathrm{m}^{3} / \mathrm{cm}^{2}$ ) which had been corrected by a factor related to the dust loading of the air during the period of measurement. The correction factor derived for each set of collections was the ratio of the volume of "standard" air required to cause a 10 percent decrease in flow of the reference paper relative to the volume required to cause a similar decrease in the reference filter. It was, in effect, the relative dust loading in the atmosphere during the collection as compared to an "average" summer day. Average dust loadings, over a 24-hour period, were quite variable, as evidenced by an approximately five to one range in values obtained for the reference filter during 20 collections. Even greater shortterm variations were observed. In this comparison it has been necessary to assume a uniform dust concentration in the air during the period of simultaneous exposure of the filters and also a linear change in filter performance with dust loading, at least during the initial phase (10 to 20 percent reduction in flow). The relative volumes of air (in cubic meters filtered per square centimeter of filter surface) required to produce a 10 percent decrease in the initial flow rate in comparable positive-displacement blower systems is presented in Table 6 . The rate of change of 
TABLE 6

Summary of Physical Characteristics of Filter Media

\begin{tabular}{|c|c|c|c|c|c|c|c|c|c|}
\hline \multirow{3}{*}{ Filter and Type } & \multirow{3}{*}{$\begin{array}{c}\text { Thickness } \\
\text { (mm) }\end{array}$} & \multirow{3}{*}{$\begin{array}{l}\text { Tensıle } \\
\text { Strength } \\
(\mathrm{Kg} / \mathrm{cm})\end{array}$} & \multirow{3}{*}{$\begin{array}{l}\text { Weight } \\
\left(\mathrm{mg} / \mathrm{cm}^{2}\right)\end{array}$} & \multicolumn{2}{|c|}{ Ash Content } & \multirow{2}{*}{\multicolumn{2}{|c|}{$\begin{array}{l}\text { Performance in } \\
\text { Standard System }\end{array}$}} & \multicolumn{2}{|c|}{ Fffect of Dust I oading } \\
\hline & & & & \multirow[b]{2}{*}{$(\%)$} & \multirow[b]{2}{*}{$\left(\mathrm{mg} / \mathrm{cm}^{2}\right)$} & & & \multirow{2}{*}{$\begin{array}{l}\text { Volume Filteted } \\
\text { dt } 10 \% \text { Reducuon } \\
\text { in Flow } \\
\left(\mathrm{m}^{3} / \mathrm{cm}^{2}\right)\end{array}$} & \multirow{2}{*}{$\begin{array}{c}\text { Decrease in } \\
\text { Flow } \\
\left(\% \text { per } \mathrm{m}^{3} / \mathrm{cm}^{2}\right)\end{array}$} \\
\hline & & & & & & $\begin{array}{c}\text { Flow } \\
\left(m^{3} / h_{1}\right)\end{array}$ & $\begin{array}{l}\text { Pressure } \\
\text { (cm Hg) }\end{array}$ & & \\
\hline \multicolumn{10}{|l|}{ C ellulose } \\
\hline Esparto & 137 & $162 \dagger$ & 249 & 025 & 0061 & 420 & 55 & $357 \pm 06(4)^{*}$ & 028 \\
\hline Gryksbo \#8 & 018 & 174 & 82 & 016 & 0014 & 338 & 109 & $195 \pm 06(2)$ & 51 \\
\hline IPC 1478 & 056 & $018 \dagger$ & 148 & 012 & 0019 & 510 & $<10$ & $>>150 \quad(3)$ & $<<01$ \\
\hline MSA BM-2133 & 183 & 058 & 327 & 012 & 0038 & 455 & 33 & $>>100(4)$ & $<01$ \\
\hline$S$ and $S 589 / 1$ & 018 & 096 & 82 & $<010$ & $<0010$ & 365 & 90 & $197 \pm 056(3)$ & 51 \\
\hline$S$ and $S 589 / 2$ & 017 & 149 & 80 & $<010$ & $<0010$ & 306 & 135 & $125 \pm 035(3)$ & 80 \\
\hline$S$ and $S 2610$ & 056 & 051 & 121 & $<010$ & 0011 & 496 & $<10$ & 87 (1) & 011 \\
\hline Struer & 018 & 152 & 76 & 020 & 0015 & 246 & 191 & $138 \pm 034(2)$ & 72 \\
\hline TFA-41 & 025 & 117 & 90 & $<010$ & $<0010$ & 352 & 101 & $250 \pm 003(2)$ & 40 \\
\hline Toyo $5 \mathrm{~A}$ & 023 & 109 & 91 & $<010$ & $<0010$ & 384 & 77 & $266 \pm 0) 52(4)$ & 38 \\
\hline Whatman \# I & 015 & 167 & 84 & 013 & 0011 & 229 & 211 & $056 \pm 0(05(15)$ & 179 \\
\hline Whatman \#41 & 025 & 141 & 89 & $<010$ & $<0010$ & 338 & 108 & $200 \pm 028(5)$ & 50 \\
\hline Whatman \#541 & 015 & 224 & 80 & $<010$ & $<0010$ & 357 & 96 & $096 \pm 025$ & 104 \\
\hline \multicolumn{10}{|l|}{ Cellulose-Asbestos } \\
\hline Draeger & 094 & 015 & 223 & 937 & 209 & 308 & 136 & $83 \pm 18(6)$ & 12 \\
\hline Draeger \#6901 & 056 & 067 & 188 & 522 & 097 & 255 & 184 & $54 \pm 07$ (3) & 19 \\
\hline $\mathrm{HV}-70$ & 023 & 078 & 82 & 2097 & 171 & 282 & 159 & $60 \pm 04(3)$ & 17 \\
\hline S-P bleu & 028 & 183 & 91 & 195 & 0178 & 447 & 36 & $128 \pm 27(4)$ & 0) 78 \\
\hline S-P jaune & 033 & 188 & 124 & 707 & 0873 & 386 & 73 & $153 \pm 16(2)$ & 076 \\
\hline S-P rose & 046 & 205 & 168 & 1616 & 272 & 297 & 144 & $132(1)$ & 075 \\
\hline Toyo HE-10 & 066 & 075 & 209 & 910 & 191 & 248 & 190 & $81 \pm 20$ & 12 \\
\hline Type 5 & 074 & $159 \dagger$ & 123 & 193 & 0233 & 488 & 12 & $310 \pm 69(3)$ & () 32 \\
\hline Type 6(Naiy N-15) & 122 & 019 & 281 & 997 & 279 & 352 & 100 & $394 \pm 106(6)$ & 025 \\
\hline \multicolumn{10}{|l|}{ Cellulose-Glass } \\
\hline Type 5G & 076 & $131 \dagger$ & 149 & 808 & 120 & 486 & 14 & $494 \pm 79(6)$ & 020 \\
\hline \multicolumn{10}{|l|}{ Glass Fiber } \\
\hline FOA-1-484 & 0 33 & 015 & 63 & 993 & b 26 & 364 & 91 & $357 \pm 7 \quad 3(4)$ & 028 \\
\hline Geiman Type A & 046 & 6) 38 & 94 & 994 & 936 & 354 & 99 & $200(20)$ & 050 \\
\hline Gelman Type E & 046 & 086 & 90 & 981 & 895 & 364 & 91 & $188 \pm 12(2)$ & 053 \\
\hline Hurlburt 934AH & 030 & 010 & 68 & 995 & 675 & 338 & 111 & $213 \pm 42(6)$ & 047 \\
\hline MSA $1106 B$ & 028 & 012 & 60 & 996 & 596 & 359 & 94 & $293 \pm 26(3)$ & 043 \\
\hline TFA-69C,F & 023 & 041 & 53 & 992 & 522 & 354 & 99 & $139 \pm 17(2)$ & 072 \\
\hline Whatman (,F/A & 025 & 011 & 55 & 990 & 549 & 360 & 93 & $270 \pm 14(5)$ & 037 \\
\hline \multicolumn{10}{|l|}{ Polystyrene } \\
\hline Microsurban & 155 & 015 & 217 & $<010$ & 0016 & 391 & 73 & $476 \pm 133(b)$ & 021 \\
\hline Delbug & 152 & 015 & 249 & $<010$ & 0016 & 319 & 125 & $347 \pm 54(3)$ & 029 \\
\hline \multicolumn{10}{|l|}{ Membrane } \\
\hline Mıllıpore AA & () 15 & 0) 29 & 48 & $<010$ & $<0010$ & 192 & 244 & $63 \pm 03(4)$ & 16 \\
\hline Polypore AM-1 & 015 & 041 & 52 & $<010$ & $<0010$ & 396 & 69 & $41 \pm 0) 8(6)$ & 24 \\
\hline Polypore AM-3 & 015 & 072 & 66 & $<010$ & $<0010$ & 31) 2 & 141 & $32 \pm 1) 5(3)$ & 31 \\
\hline
\end{tabular}

* Number of observations indicated in ( )

tFilters have a scrim backing for added strength 


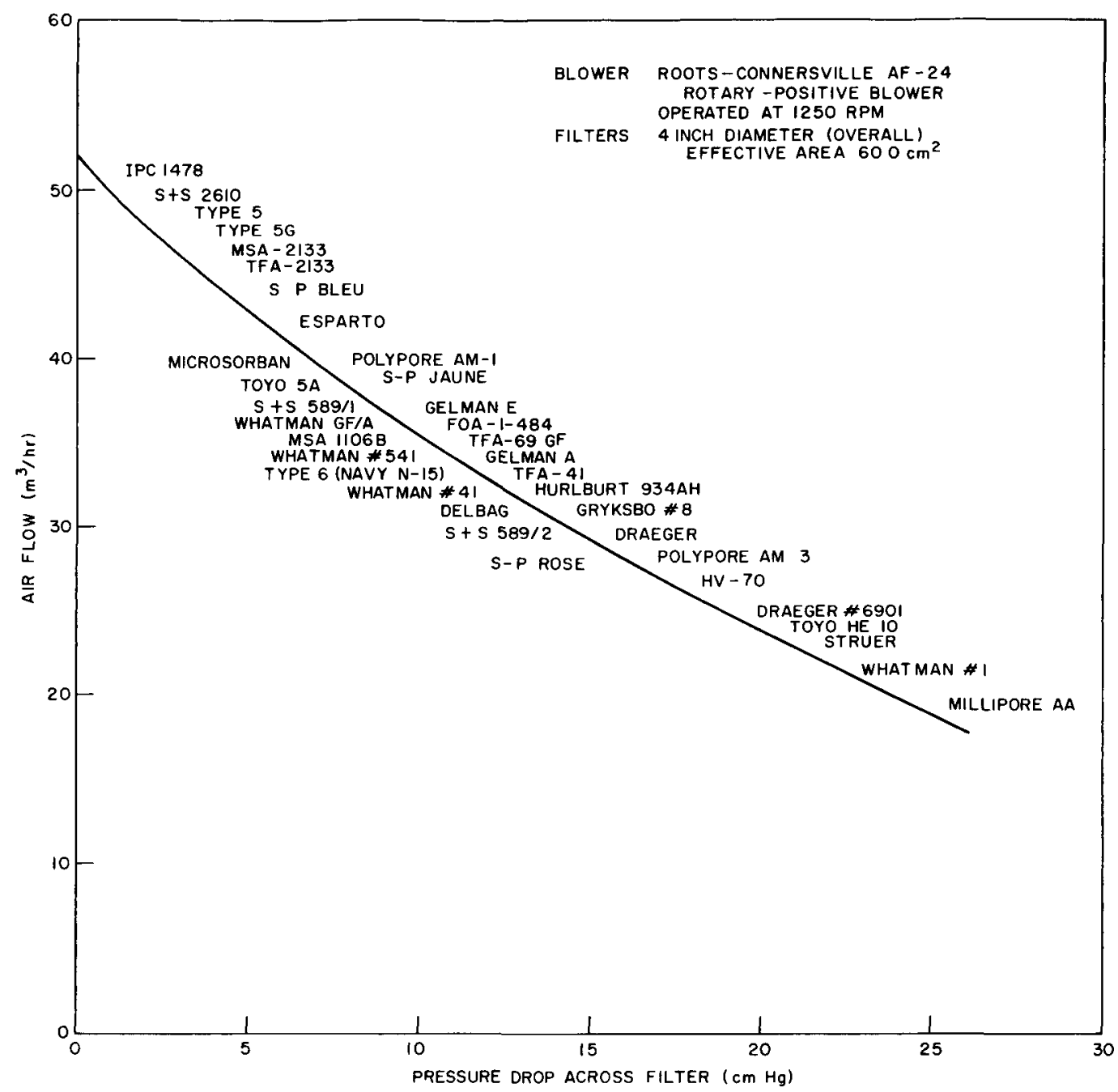

Fig 1 - Pressure flow characteristics of filter materials in a positive displacement blower system

flow with volume filtered would be greater in centrifugal or turbine-type blower systems since these generally exhibit a nonlınear flow-pressure relationship A sketch of the relative clogging rates of the varıous classes of air-filter materials is shown in Fig 2

Finally, an attempt was made to evaluate the effect of the filter media themselves as absorbers for the fission product $\beta$ activity collected during normal operations The method involved counting the front of an exposed filter, countung the back side of the filter, and then the front again with a similar clean filter interposed as an absorber between the radioactive filter and the counter $A$ rough determination of the apparent depth of penetration was made by comparıng these results with an aluminum absorption curve of a fission product collection of similar age The absorption of the bulk filter materials for fission product $\beta$ activity was dependent on the mass of the filter $\left(\mathrm{mg} / \mathrm{cm}^{2}\right)$ rather than its composition and was similar to that of an equivalent thickness $\left(\mathrm{mg} / \mathrm{cm}^{2}\right)$ of aluminum However, due to nonuniformity of the filters and variations in the dust loading of the various filters, it was not possible to determine the effective depth of penetration of the radioactive particles The insensitive counter employed in this study (effective air path and window thickness equivalent to nearly $10 \mathrm{mg} / \mathrm{cm}^{2}$ of aluminum) discriminated against the lowenergy $\beta$ 's, consequently, self-absorption corrections of only a few percent were indicated 


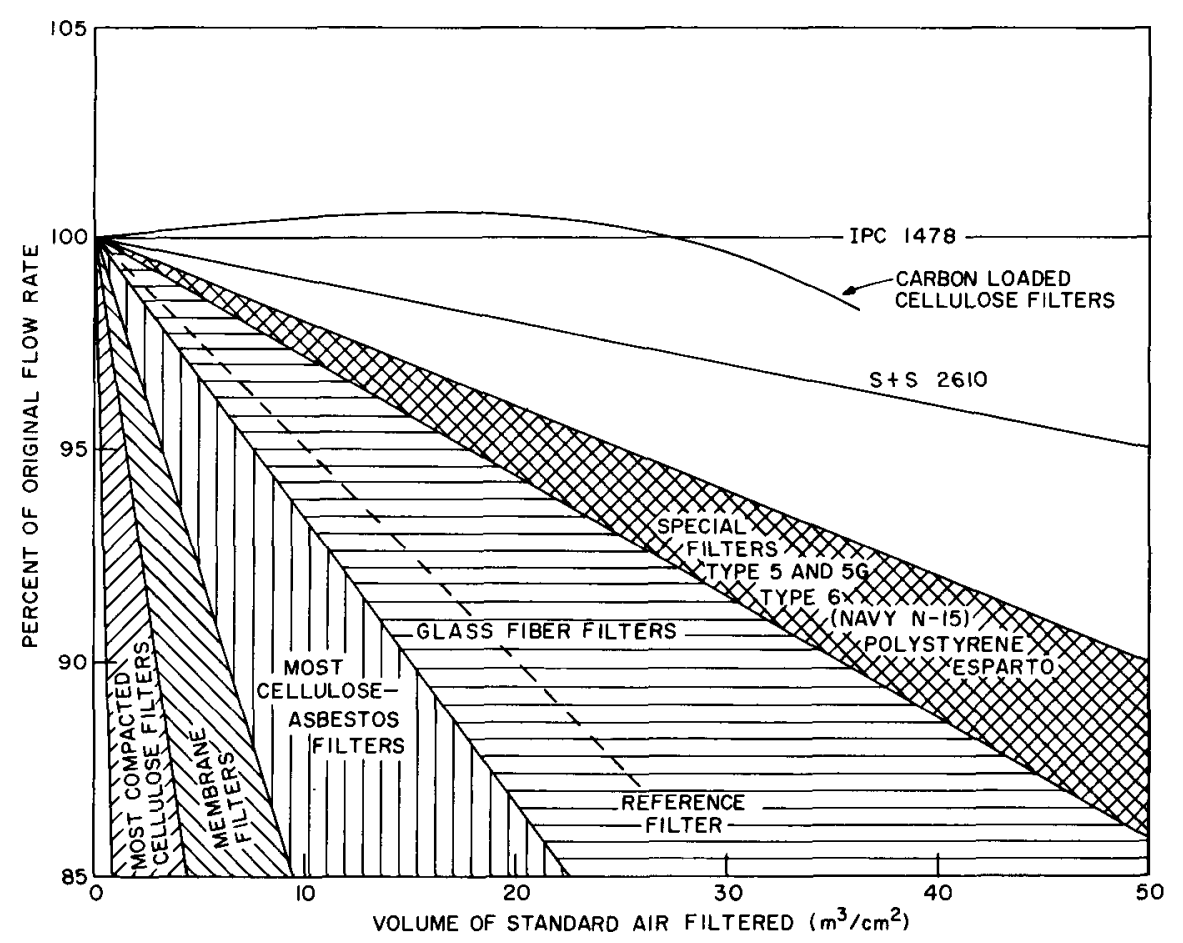

Fig. 2 - Relative clogging rates of various classes of air-filter materials

for most materials (most compacted or highdensity filters) though for a few of the thicker cellulose filters a correction near 10 percent was indicated. These corrections would be significantly greater on systems employing counters having thin windows since fission product mixtures are heavily weighted with low-energy $\beta$ emitters.

\section{CONCLUSIONS}

Since the effectiveness of any filtration method, either for the collection of aerosols or their removal from the air, depends to an important degree on the filter material that is used, the properties of the filter should be carefully considered in the design of any air-monitoring or air-purification system. In this study a number of the more important characteristics of a series of air-filter materials have been evaluated and compared so as to make possible a more scientific choice of a filter material for any particular use; no attempt is made to indicate which material should be used in any given situation.

The reported measurements indicate that the available filters cover a wide range of values in each of the physical or performance char- acteristics, permitting a balance to be reached in the filter selected for a given system or for one or more particular features to be optimized, generally at the expense of the others. The information reported covers such physical properties of the filters as the tensile strength, thickness, density, and ash content, the pressure-flow characteristics of clean filters, the effect of dust loading on filter performance, and the retentivity of the filters for various aerosols (i.e., DOP, fission products, radon daughters attached to atmospheric aerosols) as a function of air velocity through the filter.

The study of the effect of dust loading on filter performance was complicated by the dayto-day variation in the dust content of the atmosphere. It may be possible to take advantage of this observation to devise a system for monitoring the dust content of the atmosphere which depends on the measurement of the change in flow of a "standard" filter with exposure time. Such a procedure should be inherently simpler than the present practice of determining the dust content from the weight gain of an exposed filter or from densitometer readings of the blackness of the filter. 


\section{ACKNOWLEDGMENT}

The authors wish to express their appreciation to the many persons and organizations whose encouragement and cooperation have contributed to this study.

\section{REFERENCES}

1 U S Atomic Energy Commission (New York Operations Office), Health and Safety Laboratory Report "Survey of Fallout Operations," HASL-128, July 1, 1962

2 Organization for European Economic Cooperation, European Nuclear Energy Agency Report "System of Meas- urement of Environmental Radioactivity in the OEE C Countries, 1959," Report of the Health and Safety SubCommittee

3 Knudson, H W, and White, L, "Development of Smoke Penetration Meters," NRL Report P-2642, Dec 14, 1945

4 Sinclarr, D, "Physical Properties of Aerosols,' Air Pollution, Lous C. McCabe, McGraw-Hıll, p 169, 1952

5 LaMer, V K, "Preparation, Collection, and Measurement of Aerosols, Air Pollution, Louss ( McCabe, McGraw-Hill, p 607, 1952

6 Ramskıll, E A, and Anderson, W L, 'The Inertial Mechanism in the Mechanical Filtration of Aerosols, $J$ Collond Science, Vol 6, No 5, pp 416-428, Oct 1951

7 Lockhatt, I B, Jr, and Patterson, R L, Jr, 'Filteı Pack Technique for C lassifying Radiodctive Aerosols by Particle Size Part 1 - Preliminary Report and Evaluation,' NRI Report 5970, Aug 1963 


\section{UNCLASSIFIED}

U S Naval Research Report 6054 CHARACTERISTICS OF AIR FIITER MEDIA USED FOR MONITORING AIRBORNE RADIOACTIVITY, by L B I ck hart, Jr, R L Patterson, Jr, and W L Anderson 17 pp and figs March 20, 1964

A companson has been made of the more important chardeter istics of the avalable filter materials which are currently in use by varous systems for monitoring aiborne radioactivity throughou the world Most of the materials described are commercially avall be of use to those whose programs involve the employment of airfilter medid or who require such information for the design of arr-filter systems

The filter characteristics measured are such physical properties as tensile strength, thickness, denstty, ash content, retentivity toward $03 \mu$ dioctyl phthalate (DOP) aerosol particles as a function

\section{UNCLASSIFIED}

(over) able, the information herein is presented with the hope that it will

\section{UNCLASSIFIED}

Particulate hlters Materials

2 Radiodetive alt bot llle partucles - Remord

I ockhart, I B

II Patterson R I

III Anderson, W L

\section{UNCLASSIFIED}

US Naval Research Report 6054 CHARACTERISTICS OF AIR FILTER MEDIA USFD FOR MONITORING, AIRBORNF RADIOACTIVIIY, by L B lock hart, Ir, R L Pattes son, Jr, and W L Anderson $17 \mathrm{pp}$ and figs March 20, 1964

A companson has been made of the mone important characterisucs of the avalable filter materials which are currently in use by various systems for monitoring dirborne radiodctivity throughou the world Most of the materials described are commercially aval able, the information herein is presented with the hope that it will be of use to those whose programs mvolve the employment of all filter media or who require such information for the design of air-filter systems

The filter characteristics measured are such physical properties as tensile strength, thickness, density, ash content, retentivity toward $03 \mu$ dioctyl phthalate (DOP) aerosol particles as a function

\section{IINCI ASSIFIED}

\section{U S Naval Research Report 6054}

CHARACTERISTICS OF AIR FILTER MEDIA USFD FOR MONITORING AIRBORNE RADIOACTIVITY by L B Iock hart, Jr, R L Patterson, Jr, and W L Anderson $17 \mathrm{pp}$ and figs March 201964

A comparison has been made of the more important characteristucs of the avarlable filter materials which dre currently in use by various systems for monitoring arborne radioactivity throughout the world Most of the materials described are commercially avalable, the information herem is presented with the hope that it will be of use to those whose programs involve the employment of airfilter media or who require such information for the design of air filter systems

The filter characteristics medsured are such physical properties as tensile strength, thickness, density, dsh content, retentivity toward $03 \mu$ dioctyl phthalate (DOP) aerosol particles as a function
Particulate filters Materials

2 Radioacuve als borne partucles - Remora

lockhart, I B

II Patterson R I

III Anderson, W I

(over)

\section{UNCLASSIFIED}

U S Naval Research Report 6054 CHARACTERISTICS OF AIR FILTFR MEDIA USED FOR MONITORING AIRBORNE RADIOACTIVITY, by I B I okhart, Jr, R L Patterson, Jr, and $W$ J Anderson $17 \mathrm{pp}$ and figs March 20, 1964

A comparison has been made of the more important chat acter istics of the avallable filter materials which dre currently in use by vanous systems for montoring arborne radioc the world Most of the materials described are commercially avaulable, the information herein is presented with the hope that it will be of use to those whose programs involve the employment of arrfilter media or who require such information for the design of arr filter systems

The filter characteristics measured are such physical properties as tensile strength, thickness, density, ash content, retentivity toward $03 \mu$ dioctyl phthalate (DOP) aerosol particles as a function
1 Particulate filters Materids

2 Radioactive dit boune particles - Removal

I ockhart I B

II Patterson, R I

III Anderson, W I 
of arr velocity, retentivity toward aırborne fission products and natural radioactive derosols (radon daughters) at several air velocities, flow rate as a function of pressure drop across the filter, and the relative rates of clogging by atmospheric dust

The observation of a rapid change in flow with dust loading of some of the filter media suggests the systematic study of such changes as possibly a simple procedure for monitoring the dust content of the atmosphere

\section{UNCLASSIFIED}

\section{UNCLASSIFIED}

of air velocity, retentivity toward airborne fissıon products and natural radioactive aerosols (radon daughters) at several air velocities, flow rate as a function of pressure drop across the filter, and the relative rates of clogging by atmospheric dust

The observation of a rapid change in flow with dust loading of some of the filter media suggests the systematic study of such changes as possibly a simple procedure for monitoring the dust content of the atmosphere of air velocity, retentivity toward arborne fission products and natural radioactive aerosols (radon daughters) at several air velocities, flow rate as a function of pressure drop across the filter, and the relative rates of clogging by atmospheric dust

The observation of a rapid change in flow with dust loading of some of the filter media suggests the systematic study of such changes as possibly a simple procedure for montoring the dust content of the atmosphere

\section{UNCI ASSIFIED}

\section{UNCLASSIFIED}

of air velocity, retentivity toward airborne fission products and ndtural radioactive aerosols (radon daughters) at several air velocities, flow rate as a function of pressure drop across the filter, and the relative rates of clogging by atmospheric dust

The observation of a rapid change in flow with dust loading of some of the filter media suggests the systematic study of such changes as possibly a simple procedure for montoring the dust content of the atmosphere 